Intersections

Canadian Journal of Music

Revue canadienne de musique
Intersections

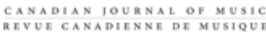

\title{
Alan Gillmor, ed. Eagle Minds: Selected Correspondence of Istvan Anhalt and George Rochberg, 1961-2005. Waterloo: Wilfrid Laurier University Press, 2007. xliii, 426 pp. ISBN 978-1-55458-018-7
}

\section{Jeremy Strachan}

Volume 31, numéro 1, 2010

URI : https://id.erudit.org/iderudit/1009291ar

DOI : https://doi.org/10.7202/1009291ar

Aller au sommaire du numéro

Éditeur(s)

Canadian University Music Society / Société de musique des universités canadiennes

ISSN

1911-0146 (imprimé)

1918-512X (numérique)

Découvrir la revue

Citer ce compte rendu

Strachan, J. (2010). Compte rendu de [Alan Gillmor, ed. Eagle Minds: Selected Correspondence of Istvan Anhalt and George Rochberg, 1961-2005. Waterloo: Wilfrid Laurier University Press, 2007. xliii, 426 pp. ISBN 978-1-55458-018-7]. Intersections, 31(1), 187-190. https://doi.org/10.7202/1009291ar

All Rights Reserved (C) Canadian University Music Society / Société de musique des universités canadiennes, 2012
Ce document est protégé par la loi sur le droit d'auteur. L’utilisation des services d'Érudit (y compris la reproduction) est assujettie à sa politique d'utilisation que vous pouvez consulter en ligne.

https://apropos.erudit.org/fr/usagers/politique-dutilisation/ 
Matravers, "Expression Theories," by Robinson herself, and "Resemblance Theories," by Saam Trivedi, the Budd works as a kind of tidying mechanismsuccinctly pulling together an issue given to messy sprawl in other forums (I wish that "Style" by Jennifer Judkins had risen to the same level). Kathleen Marie Higgins's "Visual Music and Synesthesia" is not so much a "companion" as a Wegweiser, a signpost signalling where research in this remarkable phenomenon, the confusion of sight and sound, might go. In fact, it is these basic areas of musical understanding that constitute the strength of the book. Other, more complex subjects, such as phenomenology or Adorno, simply cannot be done justice in the scope allotted the authors. Indeed, these are the strengths of the Journal of Aesthetics and Art Criticism, which as noted above is the parent journal, if only implicitly, for the Companion.

Quite apart from useful insights into potential avenues of research to be gleaned from the contributors here, the collection might have served as a text for a seminar, be it graduate or advanced undergraduate. Lacking any substantial texts on aesthetics and music, we certainly need something of that sort. But with a price tending toward $\$ 200$, it levitates itself quite out of the market, certainly the undergraduate market. (It is available as an e-book, possibly in your university's collection.) More's the shame. Perhaps one of our textbook publishers would take up the slack with a much smaller, less expensive collection suited to classroom use.

Murray Dineen

Alan Gillmor, ed. Eagle Minds: Selected Correspondence of Istvan Anhalt and George Rochberg, 1961-2005. Waterloo: Wilfrid Laurier University Press, 2007. xliii, 426 pp. ISBN 978-1-55458-018-7.

[Editor's Note: As this issue was going to press, István Anhalt passed away in Kingston, Ontario on February 242012 at the age of 92. A celebration of his life and music is being planned for a future date.]

Eagle Minds illuminates the deep intellectual and spiritual bond that composers Istvan Anhalt and George Rochberg cultivated during the course of their long friendship, documenting almost a half-century's worth of written correspondence between them. Selected and edited by the Canadian musicologist Alan Gillmor, the prolific exchange-over 250 letters written from between 1961 and Rochberg's death in 2005-comprises a detailed account of Anhalt's and Rochberg's individual pursuits as composers navigating the political and cultural tumult of the twentieth century. The collection offers a fascinating insight into both composers' personal lives as well as the lives of their worksoften from the seeds of inspiration through to their concert premieres and critical reception-unfolded in a conversation spanning Rochberg's and Anhalt's massive career arcs. Scholars with particular interest in either composer 
will find value in Eagle Minds for the uncommon wealth of biographical data contained in these letters, thanks to Rochberg's and Anhalt's diligence in keeping the other apprised of personal events in their lives, but equally to Gillmor's prodigious annotations, which help contextualize and explain the glosses, idiosyncrasies, and dense minutiae indigenous to the two composers' personal dialogue. But this volume will also hold interest for a more general audience as well, because of Gillmor's editorial acumen in locating a compelling narrative in their correspondence as it coheres organically around themes of intellectual exploration, personal identity, and the predicament of serious music in the last half of the twentieth century.

Upon their deposition at the National Library of Canada in 1985, Gillmor acted as external appraiser of Anhalt's archival materials at the request of the composer on four subsequent occasions over the next fifteen years. He explains being taken with the "richness and sheer intellectual range" of the correspondence between Anhalt and Rochberg (xiv), and soon approached Anhalt about publishing the collection. Both composers unequivocally rejected the idea initially: Rochberg wrote to Anhalt in 1991 that he wasn't even "flattered' by such "interest"' (252), and it would be another six years before Gillmor was given the composers' blessing to transcribe and edit the 400 handwritten letters of the correspondence. Thus in its broadest ambit Eagle Minds is itself nearly a quarter century in the making.

Among other published volumes of correspondences between twentiethcentury composers-such as those of Pierre Boulez and John Cage (Nattiez 1993), Paul Bowles and Ned Rorem (Lambert 1997), Gabriel Fauré and Camille Saint-Saëns (Nectoux 2004), and even the Adorno-Berg letters (Lonitz 2005) -Eagle Minds is noteworthy not only as being accessible on many levels for specialists and generalists alike, but also for the scope of the enterprise and the considerable source material at Gillmor's disposal. At 474 pages (including introduction, notes, and index), the book is compendious in the range of topics explored by Anhalt and Rochberg, which Gillmor has organized into broad sections: the beginnings of their friendship from 1961 to 1964; discussion of musical compositions during the busiest years of their careers as academics from 1965 to 1976; the years between 1981 and 1985, which saw the publication of the monographs Alternative Voices by Anhalt (1984) and The Aesthetics of Survival by Rochberg (2005); a fourteen-year period of longer ruminative letter-writing on religion, politics, and society, from 1986 to 2000 ; and finally, a section simply called "Envoi," which is also the title of a short prose piece from 1998 by Rochberg that ends The Aesthetics of Survival. This last segment, from 2001 to 2005 , contains shorter letters from the aged friends, which ends with a final note from Anhalt wishing an ailing Rochberg to "roam freely in memoryspace and be at peace" (411). Gillmor has accomplished the imposing task of carving out of this voluminous archive a book that works as both a record of individuated historical snapshots and as a surprisingly unified account of Anhalt and Rochberg's relationship as it evolved personally and intellectually.

In Gillmor's long introductory essay to the correspondence, he writes, "We are always curious to know something of a composer's musical and literary 
tastes, for such knowledge acts like a mirror of the mind, helping us to situate creative figures within a finite number of aesthetic frameworks, thereby facilitating a deeper understanding of the changing profile of their work as it responds to the expansion and layering of experience" (xxvii). This, in a sentence, is the objective of Eagle Minds, to contextualize the musical legacies of Anhalt and Rochberg within the composers' respective trajectories of experience and intellectual pursuit. Readers will take note of the many parallels in the lives of these two men, born just a year apart, who met in Stratford, Ontario, at the 1960 International Conference of Composers-a largely forgotten but important meeting that brought fifty-five delegates from Canada, the United States, and Europe to the small town known foremost for its annual Shakespeare Festival. As Gillmor notes (xvi), both composers explored and eventually abandoned serialism, one of the central topics at the 1960 conference. Where Anhalt went on to pioneer electroacoustic music in Canada and explore collage technique in the 1960s with works like Cento and Foci, Rochberg experimented principally with structural and semiological implications of musical quotation in a practice he called ars combinatoria. Both were involved in the Second World War (Anhalt as a conscripted soldier in Hungary, and a Holocaust survivor, and Rochberg as an American infantry lieutenant); both of their monographs were published at almost the same time in 1984 but evidence inherently differing attitudes and perspectives on twentieth-century composition. In fact Rochberg writes to Anhalt, after reading Alternative Voices, that despite being such close friends for so long, that they are on the "opposite end of the aesthetic poles" about musical value (140). And of course, both are Jewish. This last commonality would become a point of focus in their correspondence during the 1980 os and 1990s, as each man investigated his own relationship to Judaism, philosophically, institutionally, and even geographically—both journeyed to Israel-with increasing attention later in life.

Aspects of the contrasting temperaments of Anhalt and Rochberg are brought into relief many times over throughout their discussions on political and religious topics. As early as 1968, Rochberg writes about his growing need to reaffirm his Jewishness in a world full of "terror and fear" (74) as a source of spiritual strength. Rochberg's pessimistic bewilderment and disaffection with "this insane century" (341) and a world he "no longer recognize[s]" (105) becomes an idée fixe throughout his letters to Anhalt. On the other hand, Anhalt, whom Rochberg lauds as "more of a scholar than" he is (280), offsets the raw emotional tenor of his colleague's laments with calm and almost analytic reserve and often finds ways of positioning his current musical activities within the centre of their debates on the morass of culture and politics. In one particularly challenging and lengthy letter in January of 1985 to Rochberg, Anhalt articulates their differences in outlook: "What matters to me most, both humanly and musically speaking, is the potentiality of choice inherent in the total range over which I have a conceptual control, while envisaging personal and social interaction, as well as compositional language, process and structure. This field is, at any one moment, and at every moment, the picture of my mind" (154). 
Readers possessing a more intimate familiarity with Anhalt's compositional output - which at only about three dozen works would still be shorter, as Robin Elliott (2011) recently noted in a keynote address on Anhalt's legacy, than Wagner's Ring Cycle if played back-to-back-know the role linguistics and phonology played in steering Anhalt toward vocal composition almost exclusively since the 1970s. But in these letters we read Anhalt placing his works in a far more complex and personal continuum of history, social relations, and cultural memory. For example, Anhalt on a few occasions writes that his operas La Tourangelle and Winthrop thematically form an incomplete trilogy, along with an unrealized third work about the life of nuclear physicist J. Robert Oppenheimer. Taken together, the three operas would collectively pursue a largescale dramatic course of inquiry into French Catholicism, English Puritanism, and secular Jewishness via the life-stories of the three respective protagonists. Through his comments to Rochberg about these works, we glean some indication that Anhalt saw potential macro-thematic connections among his largest compositions emerging over decades of creation that otherwise might remain hidden from view.

It is not usual to consider the oeuvres of art music composers as examples of expressive culture per se, but Eagle Minds allows us to peer through a back door of the creative, personal, and intellectual impulses of Istvan Anhalt and George Rochberg in a way that reconciles their works irretrievably to the circumstances of their genesis-and especially so in Anhalt's case. Indeed, the letters of Anhalt and Rochberg leave with us, perhaps more than anything else, a very real sense of these two composers' music as being deeply, even uncommonly, entrenched in the histories and social worlds they inhabited.

\section{WORKs CiTed}

Anhalt, Istvan. 1984. Alternative Voices: Essays on Vocal and Choral Composition. Toronto: University of Toronto Press.

Elliott, Robin. 2011. "Istvan Anhalt: A Portrait from Memory." Paper delivered at the Canadian University Music Society / Canadian Association of Music Libraries Conference, Mount Allison University, Sackville, NB, 3 June.

Lambert, Gavin, ed. 1997. Dear Ned, Dear Paul: The Correspondence of Ned Rorem and Paul Bowles. Hanover, NH: Elysium.

Lonitz, Henri, ed. 2005. Theodor W. Adorno and Alban Berg Correspondence 1925-1935. Trans. Wieland Hoban. Cambridge, UK: Cambridge University Press, 2005.

Nattiez, Jean-Jacques, ed. 1993. The Boulez-Cage Correspondences. Cambridge, UK: Cambridge University Press.

Nectoux, Jean-Michel, ed. 2004. The Correspondence of Camille Saint-Saëns and Gabrielle Fauré: Sixty Years of Friendship, translated by J. Barrie Jones. Burlington, VT: Ashgate.

Rochberg, George. 2005. The Aesthetics of Survival: A Composer's View of Twentieth-Century Music. Ann Arbour: University of Michigan Press. 